\title{
Localisation of CD10 to biliary canaliculi by immunoelectron microscopical examination
}

\author{
S L Loke, C Y Leung, K Y Chiu, W L Yau, K N Cheung, L Ma
}

\begin{abstract}
Common acute lymphoblastic leukaemia antigen (CALLA) was first characterised in lymphoid leukaemic cells. The antigen is present in different stages of lymphoid cell differentiation as well as in subsets of myeloid cells, and further studies have also shown its presence in non-lymphoid tissues. The recent cloning and sequencing of the gene permitted deduction of its amino acid sequence which is identical with the human membrane-associated enzyme, neutral endopeptidase. Strong immunostaining for CALLA was detected in the human liver with a canalicular pattern. Immunoelectron microscopy also confirmed that the antigen was localised only in the area of the bile canaliculi. Although the function of neutral endopeptidase in the canaliculi is unknown, this antigen may prove useful in the study of biliary function and diseases.
\end{abstract}

Common acute lymphoblastic leukaemia antigen (CALLA) was originally identified and characterised as a cell surface molecule on acute lymphoblastic leukaemic cells, and was assigned the cluster of differentiation number 10 (CD10) during the First International Workshop on Human Leukocyte Differentiation Antigens.

Although original descriptions suggest that the protein is expressed only in immature lymphoid cells and their malignant counterparts, ${ }^{2}$ it soon became evident that the antigen is more widely distributed in different normal and neoplastic tissues. These include neutrophils, ${ }^{3}$ fibroblasts, ${ }^{4}$ renal epithelia, ${ }^{56}$ breast myoepithelial cells, ${ }^{57}$ fetal intestine, ${ }^{5}$ melanomas, ${ }^{8}$ gliomas, ${ }^{9}$ retinoblastomas ${ }^{10}$ and carcinomas of breast and colon. ${ }^{1112}$

Department of

Pathology, University of Hong Kong, Queen Mary Hospital, Hong

Kong

$S$ L Loke

CY Leung

$\mathrm{K}$ Y Chiu

W L Yau

$\mathrm{K}$ N Cheung

$\mathrm{L}$ Ma

Correspondence to:

Dr S L Loke

Accepted for publication

15 March 1990

\section{Methods}

Fresh normal liver parenchyma was selected from necropsy and biopsy specimens from staging laparotomy for malignant lymphoma, and lobectomy for oriental recurrent pyogenic cholangitis. A block, $1 \mathrm{~cm}^{2}$, was mounted in OCT compound (Lab-Tek division, Miles Laboratories, Inc., Naperville, Illinois, USA), snap-frozen in liquid nitrogen, and stored at $-70^{\circ} \mathrm{C}$. Another adjacent fresh tissue block, $0.5 \times 0.5 \times 0.2 \mathrm{~cm}$ in size, was immediately fixed for two hours in periodate-lysine- paraformaldehyde (PLP) fixative at $4^{\circ} \mathrm{C}$, rin-

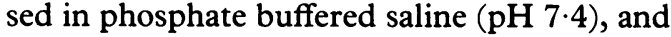
transferred to $30^{\circ}$, sucrose in phosphate buffer for "cryoprotection" (about one hour).

Monoclonal antibodies, J5 (Coulter Immunology, Hialeah, Florida, USA), and Anti-CALLA (Becton Dickinson Immunocytometry Systems, Mountain View, California, USA) are murine monoclonal antibodies of IgG2a subtype raised against tumour cells from a patient with non-T cell acute lymphoblastic leukaemia, ${ }^{1314}$ and both recognise CALLA. A monoclonal antibody of the same IgG subtype (anti-Leu-1, Becton Dickinson) was used as negative control.

IMMUNOSTAINING FOR ELECTRON MICROSCOPY

The cryoprotected tissue was rapidly frozen in liquid nitrogen and $8 \mu \mathrm{m}$ cryostat sections were cut and mounted on slides coated with gelatin. The slides were air dried for $30 \mathrm{~min}$ utes at room temperature and were further fixed in PLP for 15 minutes.

A modified streptavidin-biotin peroxidase complex (SABC) method of immunostaining using the monoclonal murine antibody $\mathrm{J} 5$ as the primary antibody, a biotinylated sheepanti-mouse immunoglobulin, and the SABC was used. ${ }^{15}$ For good ultrastructural detail, sections should be fixed for 10 minutes in $2 \cdot 5^{\circ}$ o glutaraldehyde before treating with diaminobenzidine (unpublished observations).

The sections were then post-fixed in $1^{\circ}$ 。 osmium tetroxide for one hour, washed, and dehydrated through graded alcohols and propylene oxide. Poly/Bed 812 Epoxy resin (Polysciences, Inc., Warrington, Philadelphia, USA) was dropped on to the sections and heated overnight at $60^{\circ} \mathrm{C}$ for polymerisation. The sections were "peeled-off" from the glass slides and the area of interest was selected and mounted on a dummy block with Epoxy glue. Ultrathin sections were cut and stained with uranyl acetate and lead citrate before examination under a JOEL JEM-100SX electron microscope at 80 kilovolts.

\section{IMMUNOSTAINING FOR LIGHT MICROSCOPY}

Immunostaining was performed on $6 \mu \mathrm{m}$ cryostat sections cut from the frozen block using a modified alkaline phosphatase antialkaline phosphatase (APAAP) method. ${ }^{16}$ To ensure that the signals detected were not endogenous alkaline phosphatase activity, immunostaining using the streptavidin-biotin peroxidase complex method, ${ }^{15}$ similar to that 
used for immunoelectron microscopy, was also performed.

\section{Results}

Immunostaining of the frozen sections showed consistent localisation of the antigen in a pattern that suggested canalicular binding (fig 1). No staining was observed when the first antibody $\mathrm{J} 5$ was either omitted or replaced by negative control antibody (Anti-Leu-1). Comparable results were obtained by the SABC technique. The same pattern of staining was noted when the antibody Anti-CALLA was used instead of $\mathrm{J} 5$, suggesting that the molecule recognised was actually CD10.

Immunostaining for electron microscopical examination showed predominant localisation

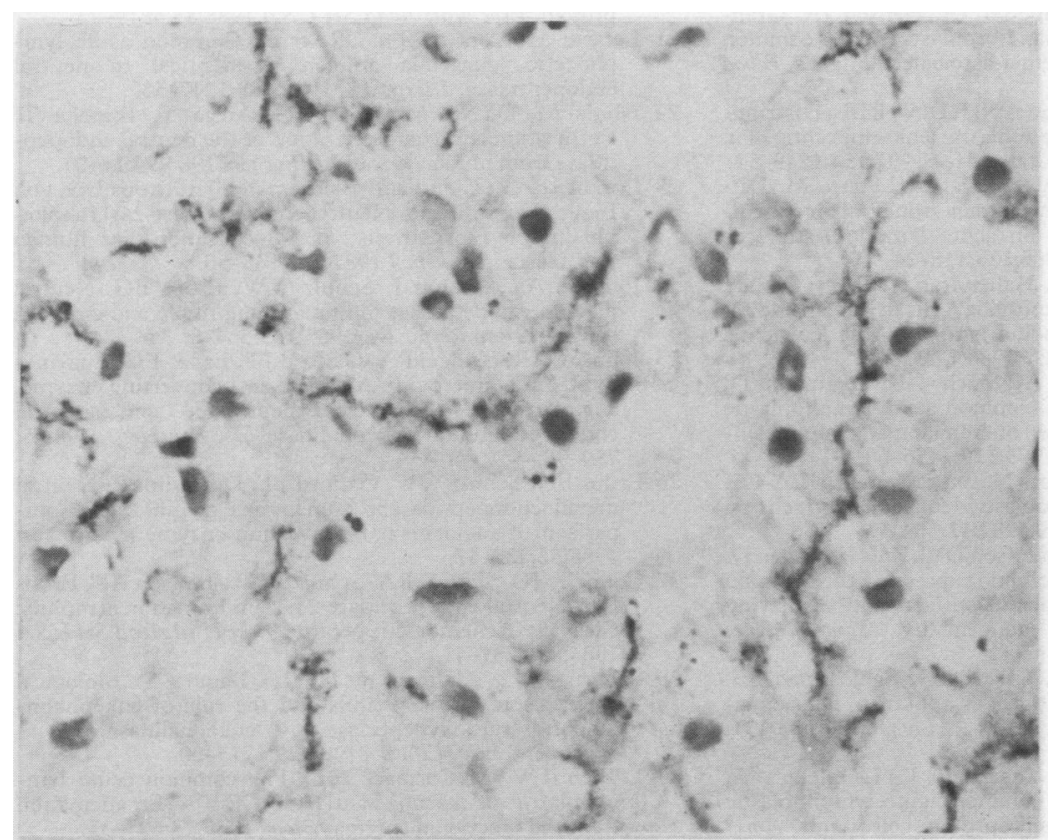

Figure 1 Photomicrograph showing the pattern of immunostaining for CD10 between hepatocytes. ( $A P A A P$.)

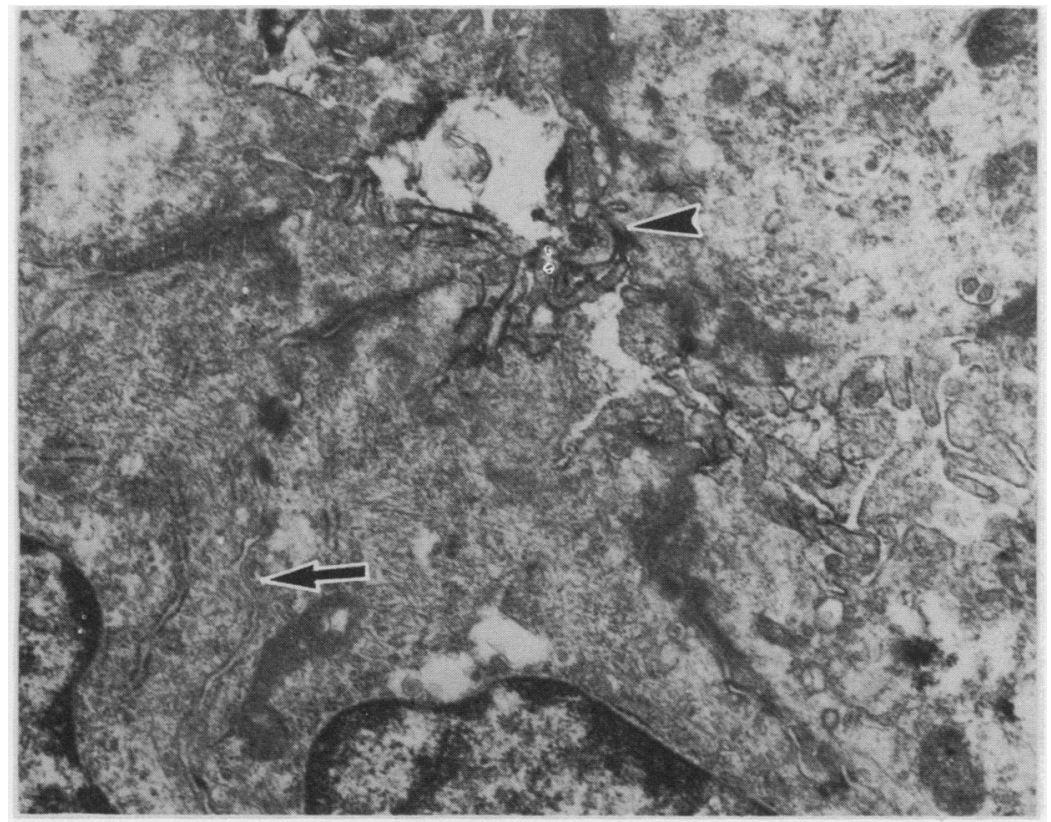

Figure 2 Immunoelectron micrograph showing localisation of electron dense chromogen product granules in the canalicular domain (arrowhead) between opposing hepatocytes. Note absence of granules outside the domain in the lateral surface (arrow) of the hepatocytes. (Counterstained with uranyl acetate and lead citrate.) of the granular, electron dense, chromogen product along the surfaces of microvilli in the bile canaliculi. The adjacent lateral surfaces of hepatocytes outside the tight junctions were not stained (fig 2). The staining was rather variable in intensity in different canaliculi, suggesting that the antigen may be distributed unevenly.

\section{Discussion}

The expression of CD10 in lymphoid cells is stage limited. It is expressed in early lymphoid cells as well as in their leukaemic counterparts where it indicates more favourable prognosis. ${ }^{17}$ The antigen is also present in follicular centre B cells, and this is sometimes useful in identifying malignant lymphomas of follicular centre cell origin.

As knowledge accumulates, it becomes apparent that some of the so-called haemic tissue specific antigens are in fact more widely distributed. ${ }^{918}$ Such realisation not only leads to a re-evaluation of the use of these markers in diagnostic pathology, but also allows them to be used for the study of normal and abnormal cell function.

We observed that $\mathrm{CD} 10$ is consistently demonstrable in the hepatocytes in a canalicular distribution. The reactivity of antiCD10 with biliary structures was also reported by Voigt et al. ${ }^{19}$ As staining is successful with two antibodies, it is unlikely that it is due to cross reaction with another antigen. The distribution on surfaces of microvilli is consistent with the predominantly surface location of the antigen in other tissues. Such location also suggests that the antigen may have a role in canalicular transport.

The isolation of the cDNA clones specific to CD10 from a pre-B ALL cell line and human kidney cDNA library, and the sequencing of the clones, has predicted a peptide sequence which is $100 \%$ identical with the human membrane-associated enzyme, neutral endopeptidase. ${ }^{2021}$

The enzyme has been characterised in human kidney, ${ }^{22}$ skin and lung fibroblasts, ${ }^{23} 24$ placental microvilli, ${ }^{25}$ epithelial cells from prostate and epididymis, ${ }^{26}$ neutrophils, ${ }^{27}$ and brain, ${ }^{28}$ most of which express CD10. Different functions have been attributed to the enzyme according to the location, ${ }^{29}$ and there is evidence that it may be required for normal chemotaxis in neutrophils. $^{30}$

The enzyme has not been biochemically characterised in the liver. The complexity of the canalicular domain and its richness in enzyme content make it difficult to detect the specific enzyme activity.

The inclusion of hepatocytes as one of the CD10 bearing tissues could affect our application of antibodies against this antigen. It is not known whether the antigen is preserved in regenerative, dysplastic, or neoplastic states of hepatocytes, and its expression might prove useful in setting more objective criteria for their distinction. It has been used in breast lesions, identifying myoepithelial cells using the antigen as a marker. On the other hand, 
caution is required in interpreting staining for CD10 in the liver for detection of secondary tumour disease, such as detection of ALL. ${ }^{19}$

Lastly, the antigen may prove to be another serum enzyme marker for canalicular or hepatic lesions, as other well recognised canalicular enzymes, such as alkaline phosphatase, have been used and it deserves further investigation.

1 Bernard A, Boumsell L, Dausset J, Milstein C, Schlossman SF (eds). Leucocyte typing. Berlin: Springer-Verlag, 1984;1-814.

2 Greaves MF, Hariri G, Newman RA, Sutherland DR, Ritter MA, Ritz J. Selective expression of the common acute lymphoblastic leukaemia (gp 100) antigen on immature lymphoblastic leukaemia (gp 100) antigen on immature 1983;61:628-39.

3 Cossman J, Neckers LM, Leonard WJ, Greene WC. Polymorphonuclear neutrophils express the common acute lymphoblastic leukaemia antigen. $J$ Exp Med 1983;157:1064-9.

4 Braun MP, Martin PJ, Ledbetter JA, Hansen JA. Granulocytes and cultured human fibroblasts express common acute lymphoblastic leukaemia-associated antigens. Blood 1983;61:718-25.

5 Metzgar RS, Borowitz MJ, Jones NH, Dowell BL. Distribution of common acute lymphoblastic leukaemia antigen in tion of common acute lymphoblastic leukaemia antigen in

6 Quackenbush EJ, Gougos A, Baumal R, Letarte M. Differential localization within human kidney of five membrane proteins expressed on acute lymphoblastic leukaemia cells. J Immunol 1986;136:118-24.

7 Gusterson BA, Monaghan P, Mahendran R, Ellis J, O'Hare $M J$. Identification of myoepithelial cells in human and rat breasts by anti-common acute lymphoblastic leukaemia antigen antibody A12. JNCI 1986;77:343-7.

8 Carrel S, Schmidt-Kessen A, Mach J-P, Haumann D, Girardet C. Expression of common acute lymphoblastic leukaemia antigen (CALLA) on human malignant melanoma cell lines. J Immunol 1983;130:2456-60.

9 Carrel S, De Tribolet N, Gross N. Expression of HLA-DR and common acute lymphoblastic leukaemia antigens on glioma cells. Eur J Immunol 1982;12:354-7.

10 Seshadri R, Matthews C, Henderson DW, Zola H, Callen D. A human retinoblastoma cell line expressing the common acute lymphoblastic leukaemia antigen and displaying an unusual chromosome abnormality. Cancer Gene Cytogenet 1986;20:345-54.

11 Pesando JM, Tomaselli KJ, Lazarus H, Schlossman SF. Distribution and modulation of a human leukaemiaassociated antigen (CALLA). J Immunol 1983;131: 2038-45.

12 Brox AG, Lavallee MC, Arseneau J, Langleben A, Major PP. Expression of common acute lymphoblastic leukaemia-associated antigen on germ cell tumor. $A m J$ Med 1986;80:1249-52

13 Ritz J, Pesando JM, Notis-McConarty J, Lazarus $H$, Schlossman SF. A monoclonal antibody to human acute lymphoblastic leukaemia antigen. Nature 1980;283:583-5.
14 Newman RA, Sutherland R, Greaves MF. The biochemical characterization of a cell surface antigen associated with acute lymphoblastic leukaemia and lymphocyte precursors. J Immunol 1981;126:2024-30.

15 Hsu SM, Raine L, Fanger H. Use of avidin-biotin-peroxidase complex $(\mathrm{ABC})$ in immunoperoxidase technique: $A$ comparison between $\mathrm{ABC}$ and unlabeled antibody (PAP) procedures. J Histochem Cytochem 1981;29:577-80.

16 Cordell JL, Falini B, Erber WN, et al. Immunoenzymatic labeling of monoclonal antibodies using immune complexes of alkaline phosphatase and monoclonal antialkaline phosphatase (APAAP Complexes). J Histochem Cytochem 1984;32:219-29.

17 Morgan E, Hsu CCS. Prognostic significance of the acute lymphoblastic leukaemia (ALL) cell-associated antigen in children with null-cell ALL. Am J Pediatr Hematol Oncol 1980;2:99-104.

18 Wahab ZA, Wright GL. Monoclonal antibody (anti-leu 7) directed against natural killer cells reacts with normal, benign and malignant prostate tissues. Int $J$ Cancer 1985;36:677-83.

19 Voigt JJ, Vinel JP, Caveriviere P, et al. Immunochemical diagnosis of hepatic localizations in malignant lymphoid diagnosis of hepatic localizations in malignant lymphoid
hematologic diseases. Study of 80 cases. Gastroenterol Clin Biol 1989;13:343-52.

20 Shipp MA, Richardson NE, Sayse PH, et al. Molecular cloning of the common acute lymphoblastic leukaemia antigen (CALLA) identifies a type II integral membrane protein. Proc Natl Acad Sci USA 1988;85:4819-23.

21 Letarte $M$, Vera $S$, Tran $R$, et al. Common acute lymphocytic leukaemia antigen is identical to neutral endopeptidase. J Exp Med 1988;168:1247-53.

22 Ishida M, Ogawa M, Kosaki G, Mega T, Ikenaka T. Purification and characterization of the neutral endopeptidase from human kidney. $J$ Biochem 1983;94:17-24.

23 Lorkowski G, Zijderhand-Bleekemolen JE, Erdös EG, von Figura K, Hasilik A. Neutral endopeptidase 24:11 (enkephalinase) biosynthesis and localization in human fibroblasts. Biochem J 1987;248:345-50.

24 Johnson AR, Ashton J, Schulz WW, Erdös EG. Neutral metalloendopeptidase in human lung tissue and cultured cells. Am Rev Respir Dis 1985;132:564-8.

25 Johnson AR, Skidgel RA, Gafford JT, Erdös EG. Enzymes in placental microvilli: Angiotensin I converting enzyme, angiotensinase A, carboxypeptidase, and neutral endopeptidase ("enkephalinase"). Peptides 1984;5: 789-96.

26 Erdös EG, Schulz WW, Gafford JT, Defendini R. Neutral metalloendopeptidase in human male genital tract: Commetalloendopeptidase in human male genital tract: Comparison to angio
$1985 ; 52: 437-47$.

27 Connelly JC, Skidgel RA, Schulz WW, Johnson AR, Erdös EG. Neutral endopeptidase $24: 11$ in human neutrophils: Cleavage of chemotactic peptide. Proc Natl Acad SciUSA 1985;82:8737-41.

28 Schwartz JC, Malfroy B, De La Baume S. Biological inactivation of enkephalins and the role of enkephalindipeptidylcarboxypeptidase ("enkephalinase") as neuropeptidase. Life Sci 1981;29:1715-20.

29 LeBien TW, McCormack RT. The common acute lymphoblastic leukaemia antigen (CD10)-Emancipation from the functional enigma. Blood 1989;73:625-35.

30 Painter RG, Dukes R, Sullivan J, Carter R, Erdös EG Johnson AR. Function of neutral endopeptidase on the Johnson AR. Function of neutral endopeptidase on the
cell membrane of human neutrophils. $J$ Biol Chem 1988;263:9456-61. 